\title{
On the Late Pliocene stone tools of the Quranwala Zone, north-west sub-Himalayas, India
}

Vidwan Singh Soni ${ }^{1, *} \&$ Anujot Singh Soni ${ }^{2}$

A recent study of the Quranwala Zone (QZ) of the north-west sub-Himalayas, India, presents evidence for anthropic activity during the Pliocene that includes a number of stone tools found in association with fossil animal bones with cut marks. Based on the date of the Pliocene rock outcrop, the tools and bones are suggested to date from $2.6 \mathrm{Ma}$ (Gaillard et al. 2016). There is, however, a question mark over the context of these tools within an outcrop of Pliocene rocks and, hence, over the date of these tools and the fossil bones. The trench from which they were excavated at Masol 2 (Gaillard et al. 2016: fig. 3) lies in a depression at the bottom of a slope; the description provided in section 2 of the paper by Gaillard et al. (2016) suggests that the stone tools may not have been in situ within the Pliocene levels, but had accumulated there and were mixed with the fragments of fossil bone due to geological processes. Moreover, many of the stone tools, such as the 'simple choppers' found in association with the fossil animal bones (Gaillard et al. 2016: figs 6, 8, 9), are usually found on much more recent sites and are therefore unlikely to date from 2.6 Ma.

Gaillard et al. (2016) provide no direct evidence, such as deep excavations or OSL dating, to prove that the stone tools and fossil bones were in situ within the Pliocene rock outcrop. More generally, any in situ evidence for stone-tool-using hominins in the sub-Himalayas could only derive from after the hills had more or less achieved their present morphology. All the tributaries of the Rivers Satluj or Ghagar were created during the uplift of the hills, with further entrenchment and subsequent changes in their courses due to tectonic activity. The lowest terraces are the youngest and were created during the terminal Pleistocene to mid Holocene. Previous work by geoarchaeologists indicates that Stone Age sites, with Soanian-type stone tools, are always found in close proximity to water courses, generally on these river terraces. The stone tools reported by Gaillard et al. from Masol were found in the vicinity of the Patiali Rao River, and should therefore post-date the formation of the landforms.

A Pliocene date is also called into question by the nature of the claimed association between the tools and the fossil bones. In their conclusion, Gaillard et al. (2016: 356) state:

1 Punjabi University Patiala, NH 64, Urban Estate Phase II, Patiala District, Patiala, Punjab 147002, India (Email: vidwansoni@gmail.com)

2 Department of Punjab Historical Studies, Punjabi University Patiala, NH 64, Urban Estate Phase II, Patiala District, Patiala, Punjab 147002, India

* Author for correspondence (Email: vidwansoni@gmail.com)

(C) Antiquity Publications Ltd, 2017 ANTIQUITY 91 357, e1 (2017): 1-6 


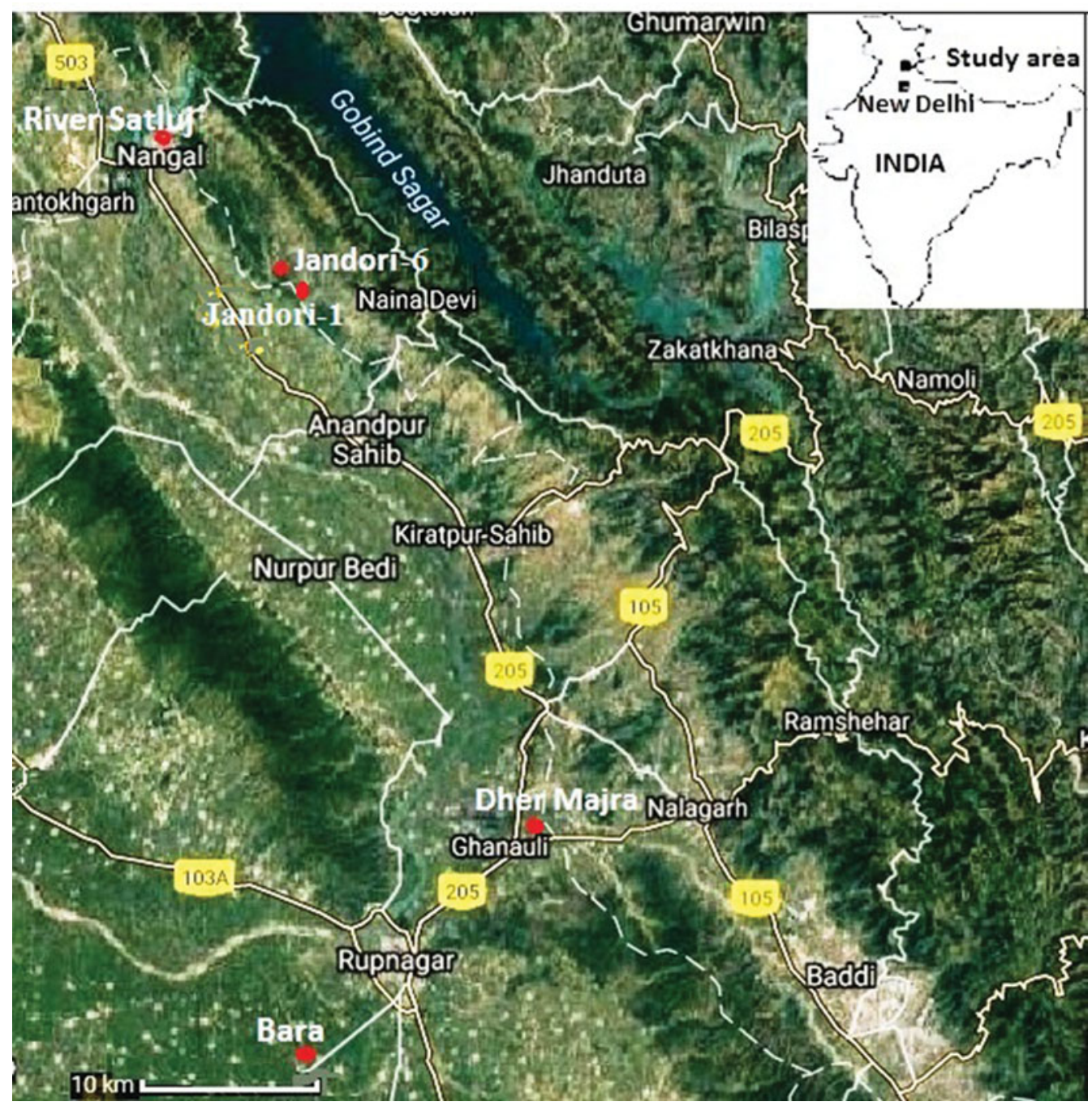

Figure 1. Map showing important mid-Holocene sites that yielded Soanian and other tool types.

These tools appear to be adapted to the size of the vertebrates present in the $Q Z$ and on the outcrops where they occur together. This systematic co-occurrence may indicate that some of the artefacts, especially the simple choppers, so far unknown in the Siwalik frontal range, may be contemporaneous with these terrestrial and fresh water vertebrates, such as the mid-size bovid, of which a bone bears cut marks.

Firstly, the statement that simple choppers are 'unknown' in the Siwalik frontal range is incorrect. Such tools are found on a number of sites in neighbouring regions where they are known — and have been for some time — as 'Soanian' tools, and are associated with the post-boulder conglomerates of late Mid Pleistocene date (Chauhan 2007; Nanda 2013: fig. 2). The claim that these tools represent a distinct 'Masol industry', limited to the (C) Antiquity Publications Ltd, 2017 


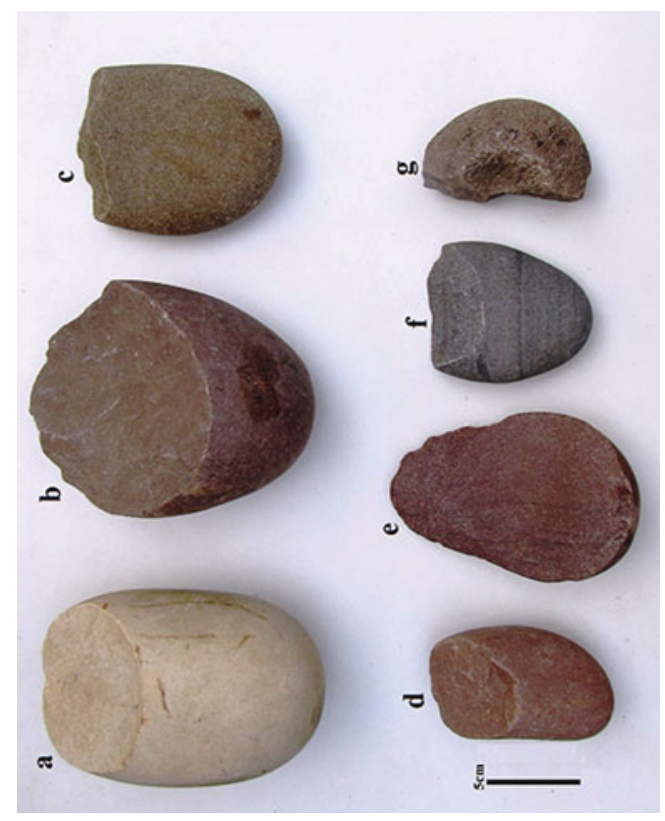

Figure 2. $a, b$, d) Simple choppers from Nangal terrace dated to the mid Holocene; c) used end-chopper from Nangal terrace; e) elongated end-chopper on flake with used working edge from Nangal terrace; $f$ ) simple chopper from the midHolocene site Jandori-1; $g$ ) half ring-stone from Jandori-1.

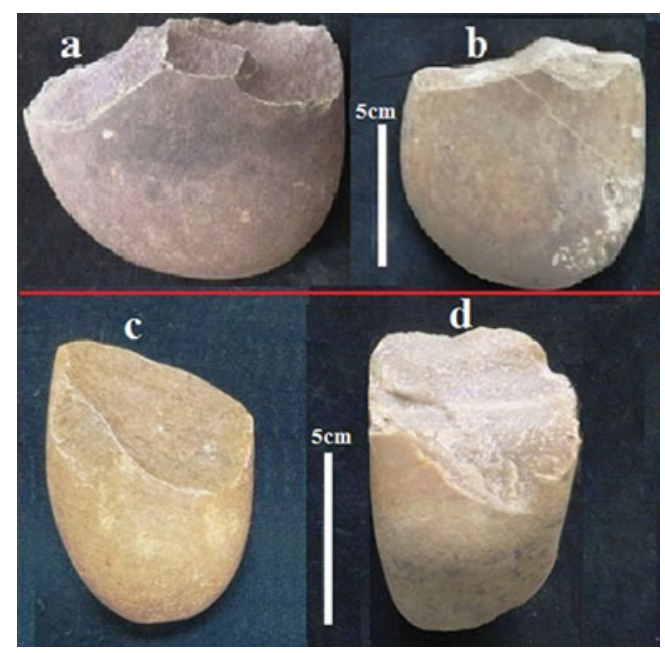

Figure 3. Choppers recovered from a confirmed late Harappan/mid-Holocene site at Bara: a) side-chopper; b) end chopper; $c-d$ ) simple choppers.
QZ and distinct from the Soanian, is repeated in another publication by the same team (Dambricourt Malassé et al. 2016: 313). In fact, the descriptions of the stone tools from the Masol region (Gaillard et al. 2016: 343-54) reveal nothing new or different from the tools found elsewhere in the sub-Himalayas.

Secondly, Gaillard et al. (2016: 356) state that "the simple choppers and flakes collected in the trial trench B1 at Masol 2 and on the outcrops of the QZ could be associated with the scavenging activity evidenced 200m apart at Masol 1". What sort of scavenging activity might have been separated by $200 \mathrm{~m}$ ?

Thirdly, fig. 8 of Dambricourt Malassé et al. (2016) shows a chopper that appears to have fallen from the surface of a small butte and to have been deposited below on the butte's wall; as such, the chopper is not in situ. The explorers also observed several stone tools scattered below and around the butte. It is possible that, a few thousand years ago, the butte had a larger planar surface where people made and used stone tools; subsequent erosion reduced the area of the butte, with the tools redeposited below.

Hence, the alleged uniqueness of the tools, their stratigraphic context and their association with the fossil bones are all open to question.

In fact, many similar stone tools have been recently discovered from midHolocene sites in the region (Figures $1 \&$ 2). Most of these tools were recovered from mid-Holocene terraces on the River Satluj and its tributaries; OSL dating confirms the age of these terraces and the associated stone tools. For example, a terrace of the River Satluj at Nangal has been OSL-dated to the mid-Holocene (Table 1). Figure 2 (a-e) shows tools recovered from the

(C) Antiquity Publications Ltd, 2017 
Table 1. OSL dating of soil samples of mud deposition underlying the stone tools on the terrace NGT-2 of the River Satluj at Nangal. Material-sediment sample: mineral used-quartz, size: 90-125 micrometre SAR protocol.

\begin{tabular}{l|c|c|c|c|c|c|c|c}
\hline Lab no. & $\begin{array}{c}\text { Sample } \\
\text { depth from } \\
\text { surface }(\mathbf{c m})\end{array}$ & $\mathrm{U}(\mathbf{p p m})$ & $\begin{array}{c}\mathrm{Th} \\
(\mathrm{ppm})\end{array}$ & $\begin{array}{c}\text { Potassium } \\
\mathrm{K}(\%)\end{array}$ & $\begin{array}{c}\text { Moisture } \\
\text { content } \\
(\%)\end{array}$ & $\begin{array}{c}\text { Equivalent } \\
\text { dose } \\
(\mathrm{De}) \mathrm{Gy}\end{array}$ & $\begin{array}{c}\text { Dose rate } \\
(\mathrm{Gy} / \mathrm{ka})\end{array}$ & Age (ka) \\
\hline LD874 & 55 & $2.64 \pm 0.3$ & $14 \pm 1.4$ & $1.64 \pm 0.2$ & 7.06 & $14.84 \pm 1.6$ & $3.10 \pm 0.2$ & $4.79 \pm 0.6$ \\
\hline
\end{tabular}

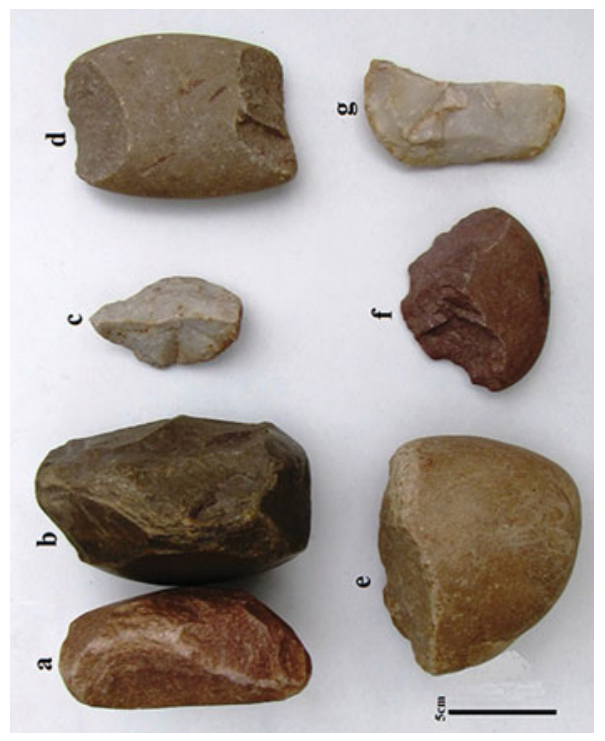

Figure 4. Stone tools from late Harappan site Dher Majra: $a-b)$ chopping tools showing battered edges; $c$ ) pointed unifacial prismatic core; d) bi-ended cutting tool; e) end-chopper with abraded edge; f) triangular chopper; g) unifacial end-scraper.

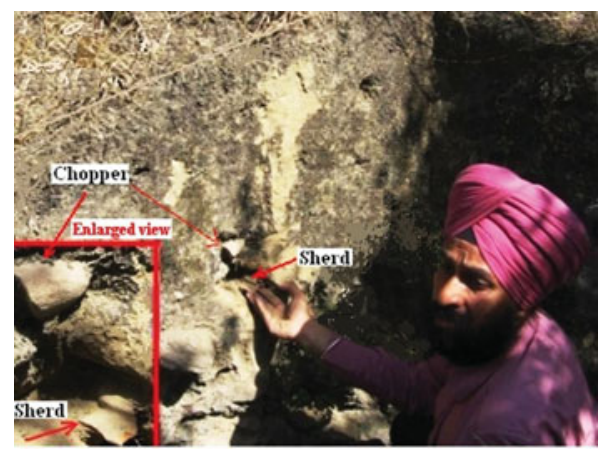

Figure 5. In situ chopper and a late Harappan potsherd being recovered from the excavation of Jandori-6 by Anujot Singh Soni.

(C) Antiquity Publications Ltd, 2017 terrace; the raw material was collected from the boulder conglomerates. A rich lithic assemblage (Figure 2: $\mathrm{f}-\mathrm{g}$ ) was recovered from another mid-Holocene site named Jandori-1 (Soni \& Soni 2013).

A probable mid-Holocene date for Gaillard et al.'s (2016) so-called 'Masol-type' stone tools is further suggested by the presence of similar tools at late Harappan sites such as Bara and Dher Majra of District Ropar, Punjab (Soni \& Soni 2012). A selection of stone tools from these sites is shown in Figures 3 and 4 respectively. Such tools have also been recovered from the excavated context of a confirmed late Harappan/midHolocene site in Himachal Pradesh (Soni \& Soni 2012). The in situ presence of stone tools with pottery is shown in Figure 5, and a selection of tools from this excavated site is shown in Figure 6. In summary, the simple choppers' that Gaillard et al. (2016) claim to be associated with $2.6 \mathrm{Ma}$ anthropic activity and present only in the Siwalik frontal range are, in fact, found widely in mid-Holocene contexts. This strongly suggests that none of the stone tools recovered from Masol is associated with anthropic activity of a late Pliocene date. As such, there is no evidence on which to argue for the presence of hominins in this region during the late Pliocene. Currently, there is nothing to suggest that stone-toolusing humans were present in the subHimalayas earlier than the terminal Pleistocene to mid Holocene. 


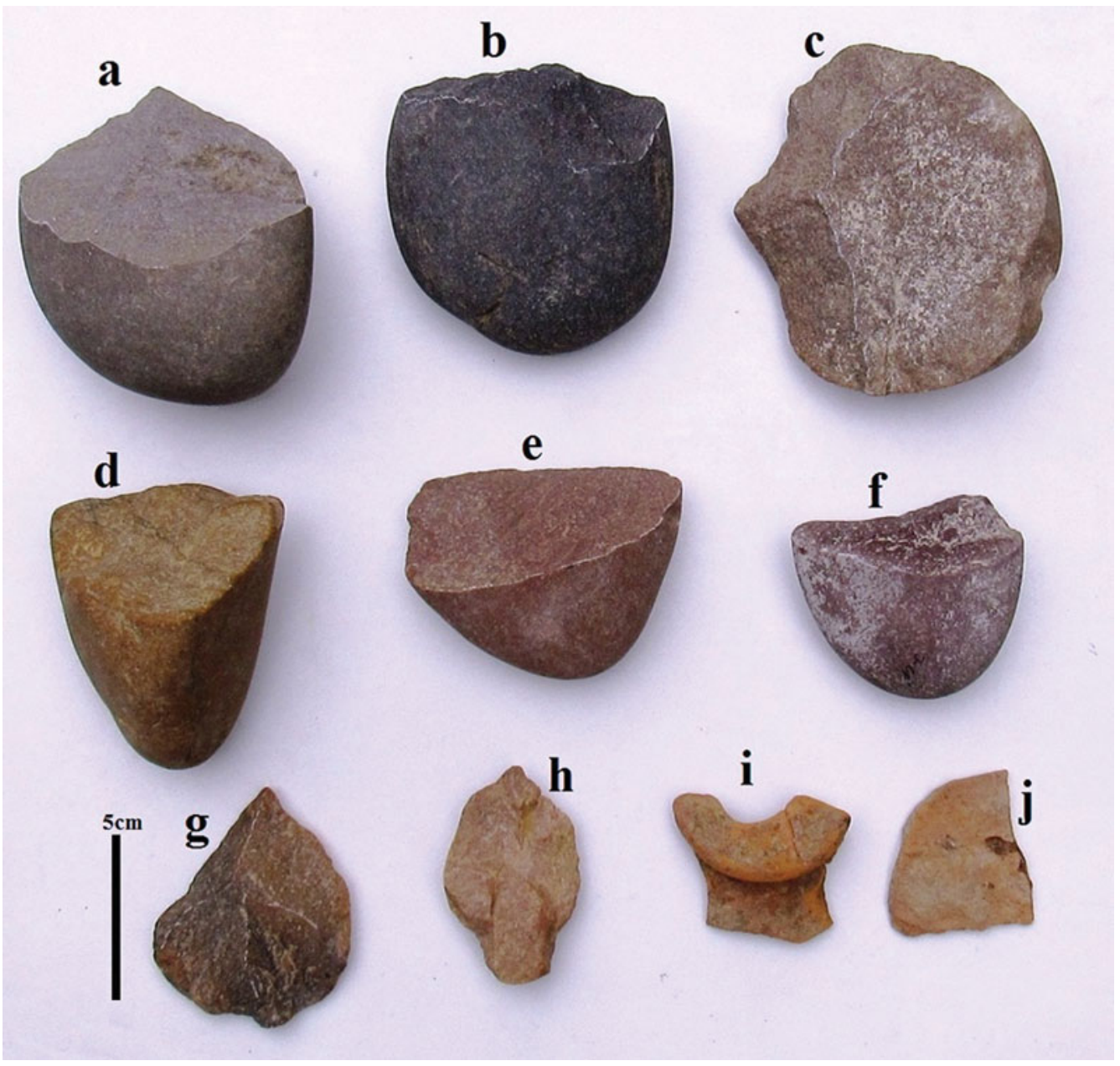

Figure 6. Material found from the excavation of Jandori-6: a) pointed chopper; b) end-chopper; c) pointed side-chopper on a thick first flake; $d-f$ ) simple choppers; $g$ ) Levalloisian point; h) projectile point; $i-j)$ late Harappan potsherds.

\section{Acknowledgements}

We are thankful to K.C. Nauryal for inviting us to the late Harappan mound Bara, to V. Shinde for identifying the pottery recovered from the excavation, and to A.S.I. New Delhi for granting us permission for the excavation of the Jandori site and for allowing us to explore the Punjab and Himachal Pradesh regions at various times.

\section{References}

Chauhan, P. 2007. Soanian cores and core-tools from Toka, northern India: towards a new typo-technological organization. Journal of Anthropological Archeology 26: 412-41. https://doi.org/10.1016/j.jaa.2007.01.001
Dambricourt Malassé, A., M. Singh, B. Karir, C. Gaillard, V. Bhardwaj, A.M. Moigne, S. Abdessadok, C.C. Sao, J. Gargani, A. Tudryn, T. Calligaro, A. Kaur, S. Pal \& M. Hazarika. 2016. Anthropic activities in the fossiliferous Quranwala Zone, 2.6 Ma, Siwaliks of north-west India, historical context of the discovery and scientific investigations. Comptes Rendus Palevol 3: $295-316$. https://doi.org/10.1016/j.crpv.2015.06.004.

(C) Antiquity Publications Ltd, 2017 
Gaillard, C., M. Singh, A. Dambricourt Malassé, V. Bhardwaj, B. Karir, A. Kaur, S. Pal,

A.M. Moigne, C. Chapon Sao, S. Abdessadok, J. GARGANi \& A. Tudryn. 2016. The lithic industries on the fossiliferous outcrops of the Late Pliocene Masol formation, Siwalik frontal range, north-western India (Punjab). Comptes Rendus Palevol 3: 341-57. https://doi.org/10.1016/j.crpv.2015.09.017.

NANDA, A.C. 2013. Upper Siwalik mammalian faunas of the Himalayan foothills. Journal of the Palaeontological Society of India 58: 75-86.
Soni, V.S. \& A.S. Soni. 2012. New observations on the age and context of Soanian artefacts in the north-western sub-Himalayas of India. Bulletin of the Indo Pacific Prehistory Association 32: 6-18.

- 2013. Stone Age persisted in north-western sub-Himalayas up to mid-Holocene times: evidence found in India. Indian Journal of Physical Anthropology \& Human Genetics 32: 71-95.

(C) Antiquity Publications Ltd, 2017 